\title{
Calibration and functional analysis of three genetically encoded $\mathrm{Cl}^{-} / \mathrm{pH}$ sensors
}

\section{Mukhtarov ${ }^{1,2}$, L. Liguori ${ }^{3}$, T. Waseem ${ }^{1,4}$, F. Rocca ${ }^{3,5}$, S. Buldakova ${ }^{1}$, D. Arosio ${ }^{3 *}$ and P. Bregestovski ${ }^{1 *}$}

1 Brain Dynamics Institute, Inserm UMR1106, Aix-Marseille University, Marseille, France

${ }^{2}$ Laboratory of Neurobiology, Institute of Fundamental Medicine and Biology, Kazan Federal University, Kazan, Russia

${ }^{3}$ Institute of Biophysics, National Research Council and FBK, Trento, Italy

${ }^{4}$ Institute of Biophysics and Cell Engineering, National Academy of Sciences, Minsk, Belarus

${ }^{5}$ Physics Department, University of Trento, Trento, Italy

\section{Edited by:}

Pau Gorostiza, Catalan Institution for Research and Advanced Studies,

Spain

\section{Reviewed by:}

Colin J. Akerman, University of Oxford Academic Research Fellow, UK

Alexandre Mourot, Université Pierre et Marie Curie, France

\section{*Correspondence:}

D. Arosio, Institute of Biophysics, National Research Council and FBK, Trento, Italy.

e-mail:daniele.arosio@cnr.it;

P. Bregestovski, Brain Dynamics Institute, Inserm UMR1106, Aix-Marseille University,

27 Boulevard Jean Moulin, 13385

Marseille Cedex 05, France.

e-mail:piotr.bregestovski@ univmed.fr
Monitoring of the intracellular concentrations of $\mathrm{Cl}^{-}$and $\mathrm{H}^{+}$requires sensitive probes that allow reliable quantitative measurements without perturbation of cell functioning. For these purposes the most promising are genetically encoded fluorescent biosensors, which have become powerful tools for non-invasive intracellular monitoring of ions, molecules, and enzymatic activity. A ratiometric CFP/YFP-based construct with a relatively good sensitivity to $\mathrm{Cl}^{-}$has been developed (Markova et al., 2008; Waseem et al., 2010). Recently, a combined $\mathrm{Cl}^{-} / \mathrm{pH}$ sensor (ClopHensor) opened the way for simultaneous ratiometric measurement of these two ions (Arosio et al., 2010). ClopHensor was obtained by fusion of a red-fluorescent protein (DsRed-monomer) to the $E^{2} \mathrm{GFP}$ variant that contains a specific $\mathrm{Cl}^{-}$-binding site. This construct possesses $\mathrm{p} K_{a}=6.8$ for $\mathrm{H}^{+}$and $K_{d}$ in the $40-50 \mathrm{mM}$ range for $\mathrm{Cl}^{-}$at physiological $\mathrm{pH}$ ( 7.3). As in the majority of cell types the intracellular $\mathrm{Cl}^{-}$concentration $\left(\left[\mathrm{Cl}^{-}\right]_{i}\right)$ is about $10 \mathrm{mM}$, the development of sensors with higher sensitivity is highly desirable. Here, we report the intracellular calibration and functional characterization of ClopHensor and its two derivatives: the membrane targeting PalmPalm-ClopHensor and the H148G/V224L mutant with improved $\mathrm{Cl}^{-}$affinity, reduced $\mathrm{pH}$ dependence, and $\mathrm{p} K_{a}$ shifted to more alkaline values. For functional analysis, constructs were expressed in $\mathrm{CHO}$ cells and $\left[\mathrm{Cl}^{-}\right]_{i}$ was changed by using pipettes with different $\mathrm{Cl}^{-}$concentrations during whole-cell recordings. $K_{d}$ values for $\mathrm{Cl}^{-}$measured at $33^{\circ} \mathrm{C}$ and $\mathrm{pH} \sim 7.3$ were, respectively, 39, 47, and $21 \mathrm{mM}$ for ClopHensor, PalmPalm-ClopHensor, and the H148G/V224L mutant. PalmPalm-ClopHensor resolved responses to activation of $\mathrm{Cl}^{-}$-selective glycine receptor (GlyR) channels better than did ClopHensor. Our observations indicate that these different ClopHensor constructs are promising tools for non-invasive measurement of $\left[\mathrm{Cl}^{-}\right]_{i}$ in various living cells.

Keywords: fluorescent biosensors, intracellular chloride, intracellular pH, non-invasive monitoring, optogenetics

\section{INTRODUCTION}

Beginning with the pioneer studies by Tsien and co-authors on measurements of intracellular calcium concentration in intact lymphocytes (Tsien et al., 1982), non-invasive monitoring of different intracellular ions $\left(\mathrm{Ca}^{2+}, \mathrm{Mg}^{2+}, \mathrm{Cl}^{-}\right.$, and $\left.\mathrm{H}^{+}\right)$has became a powerful direction of research for functional analysis of neurons and other cell types under normal and pathophysiological conditions.

Among several methods proposed for monitoring intracellular $\mathrm{Cl}^{-}$concentration $\left(\left[\mathrm{Cl}^{-}\right]_{i}\right)$, the most promising is the use of genetically encoded $\mathrm{Cl}^{-}$-sensitive probes (Bregestovski et al., 2009; Mancuso et al., 2011). The first generation of probes named "Clomeleon" (Kuner and Augustine, 2000) and "ClSensor" (Markova et al., 2008) was based on the $\mathrm{Cl}^{-}$-sensitive yellow-fluorescent protein (YFP) linked with $\mathrm{Cl}^{-}$-insensitive cyan-fluorescent protein (CFP), which was the reference fluorescence molecule. These indicators have opened the way for noninvasive monitoring and ratiometric measurement of $\left[\mathrm{Cl}^{-}\right]_{i}$ in different cell types in vitro (Pellegrino et al., 2011; Bertollini et al., 2012; Friedel et al., 2013). Expressed in neurons of transgenic mice, they have allowed imaging of $\mathrm{Cl}^{-}$dynamics in inhibitory circuits of different brain areas, including hippocampus, cerebellum, and deep cerebellar nuclei (Berglund et al., 2008, 2011), as well as in intact hippocampus (Dzhala et al., 2012) and a dorsal root ganglia preparation (Batti et al., 2013). Producing a construct consisting of a glycine receptor (GlyR) with Cl-Sensor incorporated into the long cytoplasmic domain (BioSensorGlyR) provided a tool for non-invasive monitoring activity of these $\mathrm{Cl}^{-}$-selective receptor-operated channels (Mukhtarov et al., 2008). 
The recently proposed combined $\mathrm{Cl}^{-} / \mathrm{pH}$ sensor (ClopHensor) opened the way for simultaneous ratiometric measurement of these two ions (Arosio et al., 2010). ClopHensor is obtained by fusion of a red-fluorescent protein (DsRedmonomer) to the $\mathrm{E}^{2} \mathrm{GFP}$ variant that contains a specific $\mathrm{Cl}^{-}$-binding site. This construct is particularly promising as it allows simultaneous monitoring of $\left[\mathrm{Cl}^{-}\right]_{i}$ and intracellular $\mathrm{pH}\left(\mathrm{pH}_{i}\right)$ in the same cells (Arosio et al., 2010; Bregestovski and Arosio, 2011; Raimondo et al., 2012). At physiological $\mathrm{pH}$ $(\sim 7.3)$, ClopHensor possesses $\mathrm{p} K_{a}=6.8$ for $\mathrm{H}^{+}$and $K_{d}$ in the 40-50 mM range for $\mathrm{Cl}^{-}$. As in the majority of cell types the intracellular $\mathrm{Cl}^{-}$concentration is about $10 \mathrm{mM}$ (Khirug et al., 2008; Tyzio et al., 2008; Bregestovski et al., 2009), development of sensors with higher sensitivity is necessary.

Here, we present calibration and functional analysis of ClopHensor and two of its derivatives: (i) PalmPalm-ClopHensor, which should have preferable membrane targeting and thus allow near-membrane measurement of $\left[\mathrm{Cl}^{-}\right]_{i}$ and $\mathrm{pH}_{i}$; and (ii) ClopHensor with mutations H148G and V224L aimed to increase the affinity of this probe for $\mathrm{Cl}^{-}$and change the $\mathrm{pH}$-sensing properties. It has been previously demonstrated that the V224L mutation increases the affinity for $\mathrm{Cl}^{-}$by an order of magnitude (Arosio et al., 2011), while the H148G mutation increases the $\mathrm{p} K_{a}$ value by $1 \mathrm{pH}$ unit in YFP (Elsliger et al., 1999) as well as in GFP (Hanson et al., 2002). Here, we combined the H148G and the V224L mutations in $\mathrm{E}^{2} \mathrm{GFP}$ in order to: (1) shift the $K_{d}$ for $\mathrm{Cl}$ to the lower $\mathrm{mM}$ range, and (2) increase the $\mathrm{p} K_{a}$ of the GFP sensing element to more alkaline values.

For these three constructs, calibrations determining their sensitivity to $\mathrm{Cl}^{-}$and $\mathrm{H}^{+}$in living cells were obtained. Also presented are the distributions of these probes in cells and simultaneous recording of changes in $\left[\mathrm{Cl}^{-}\right]_{i}$ and $\mathrm{pH}_{i}$ during activation of $\mathrm{Cl}^{-}$-selective GlyR channels.

\section{MATERIALS AND METHODS \\ PRODUCING AND CLONING OF ClopHensor VARIANTS}

The ClopHensor, E $E^{2}$ GFP-DsRedm, construct was mutated at two residues, H148G and V224L, of the GFP domain. Two sequential site-directed mutagenesis were performed using QuickChange II XL Site-Directed Mutagenesis Kit (Stratagene) following the manufacturer's protocol. Complementary primers were synthesized by Sigma-Aldrich with the following sequences: H148G-fw GAGTACAACTACAACAGCGG CAACGTCTATA TCATGG; H148G-rv CCATGATATAGACGTTGCCGCTGTTGT AGTTGTACTC; V224L-fw CTGCTGGAGTTCCTGAACGC CGCCG; V224L-rv CGGCGGCGTTCAGGAACTCCAGCAG and were used to amplify the entire plasmid in a PCR reaction using high-fidelity polymerase. To eliminate template, the PCR reaction was digested with Dpn1. The amplified mutated DNA was purified using Wizard SV Gel and the PCR Clean-up System kit (Promega), and transformed into Escherichia coli XL10Gold ultracompetent cells (Novagen), which were then grown overnight on LB plates supplemented with $50 \mathrm{mg} / \mathrm{l}$ ampicillin at $37^{\circ} \mathrm{C}$.

Four positive colonies were picked and grown overnight in $3 \mathrm{ml}$ of $\mathrm{LB}$-ampicillin at $37^{\circ} \mathrm{C}$ under shaking for mini prep DNA extraction (Wizard ${ }^{\circledR}$ Plus SV Minipreps DNA Purification;
Promega). All the constructs were verified by sequencing the entire insert. Finally, plasmids used for transfection were prepared using the QIAGEN Plasmid Plus Maxi kit.

\section{EXPRESSION AND PURIFICATION OF THE H148G/V224L MUTANT}

The recombinant GFP variant was expressed as Strep-tagged protein in Escherichia coli BL21 (Novagen) and harvested $20 \mathrm{~h}$ after induction with $1 \mathrm{mM}$ IPTG at $30^{\circ} \mathrm{C}$. Purification by affinity was carried out using Strep-Tactin Superflow 5-ml cartridges (IBA, GmbH, Germany), following the manufacturer's instructions, at $4^{\circ} \mathrm{C}$ in an AKTA Basic10 FPLC system (GE Healthcare Europe, Milan, Italy) with continuous monitoring of optical densities at $280 \mathrm{~nm}$. The use of $\mathrm{Cl}^{-}$-free buffers in the final purification step ensured the complete removal of $\mathrm{Cl}^{-}$from the preparation. Diethanolamine (DEA; $20 \mathrm{mM}$ ) in $50 \mathrm{mM} \mathrm{K}_{2} \mathrm{SO}_{4}$ adjusted to $\mathrm{pH} 8.5$ was supplemented with a cocktail of protease inhibitors (Roche). Lysis was performed with an Ultrasonic Processor (Cole Parmer) (10 cycles of $30 \mathrm{~s}$, output $6 \mathrm{~W}$, and $10 \mathrm{~s}$ cooling). FPLC was performed on an AKTA Basic10 FPLC system (GE Healthcare) using a Strep-Tactin Superflow $5 \mathrm{ml}$ column (IBA Technology). Filtered lysate was loaded without a loop, and the flow rate was set at $3 \mathrm{ml} / \mathrm{min}$. Elution of bound strep-tagged GFP was obtained in 75\% washing buffer $2.5 \mathrm{mM}$ desthiobiotin. Protein Concentration was determined by BCA ${ }^{\mathrm{TM}}$ Protein Assay (Pierce Protein Biology Products, USA).

\section{CELL CULTURE PREPARATION}

For fluorescence analysis of $\left[\mathrm{Cl}^{-}\right]_{i}$ and $\left[\mathrm{H}^{+}\right]_{i}$, and also for immunocytochemistry and electrophysiology, ClopHensor constructs and human $\alpha 1$ GlyR subunits were expressed in $\mathrm{CHO}$ cells and in neurons of primary culture by means of Lipofectamin transfection.

Chinese hamster ovary ( $\mathrm{CHO}-\mathrm{K} 1)$ cells were obtained from the American Type Tissue Culture Collection (ATCC, Molsheim, France) and maintained as previously described (Medina et al., 2000; Waseem et al., 2010). One day before the transfection, cells were plated onto coverslips (12-14 $\mathrm{mm}$ in diameter), which were placed inside $35-\mathrm{mm}$ cell culture dishes with $2 \mathrm{ml}$ of medium. $\mathrm{CHO}-\mathrm{K} 1$ cells were transfected with approximately $1 \mu \mathrm{g} / 1 \mu \mathrm{l}$ cDNA of constructs, using the Lipofectamine 2000 transfection protocol (Life Technology, USA). Three hours after the initial exposure of the cells to the cDNAs, a fresh cDNA-containing solution replaced the old one.

Neurons of hippocampal culture from 18-day rat embryos were dissociated using trypsin and plated at a density of 70,000 cells $\mathrm{cm}^{-2}$ in minimal essential medium (MEM) supplemented with 10\% NU serum (BD Biosciences, Le Pont de Claix, France), $0.45 \%$ glucose, $1 \mathrm{mM}$ sodium pyruvate, $2 \mathrm{mM}$ glutamine, and 10 $\mathrm{IU} \mathrm{ml} \mathrm{ml}^{-1}$ penicillin-streptomycin as previously described (Buerli et al., 2007). On days 7, 10, and 13 of culture incubation, half of the medium was changed to MEM with 2\% B27 supplement (Invitrogen).

Transfections of neuronal cultures at 7-10 days in vitro (DIV) were performed as described previously (Buerli et al., 2007; Pellegrino et al., 2011). Cells were used in experiments 2-5 days after transfection. 


\section{INTRACELLULAR CL- CALIBRATION OF ClopHensor VARIANTS}

For $\mathrm{Cl}^{-}$calibration we used whole-cell recordings with different $\mathrm{Cl}^{-}$concentrations in recording pipettes. Whole-cell patch-clamp recordings on $\mathrm{CHO}$ cells were conducted $24-48 \mathrm{~h}$ after transfection, using an EPC-9 amplifier (HEKA Elektronik, Germany) at a holding potential -20 or $-30 \mathrm{mV}$ and at a temperature of $32-33^{\circ} \mathrm{C}$. Cells were bathed in a solution containing $(\mathrm{mM})$ : $\mathrm{NaCl} 126 ; \mathrm{KCl} 3.5 ; \mathrm{CaCl}_{2} 2 ; \mathrm{MgCl}_{2} 1.3 ; \mathrm{NaH}_{2} \mathrm{PO}_{4} 1.2 ; \mathrm{NaHCO}_{3}$ 25 ; and D-glucose 10; equilibrated at $\mathrm{pH} 7.4$ with $95 \% \mathrm{O}_{2}$ and $5 \% \mathrm{CO}_{2} ; 320 \mathrm{mOsm}$. The patch pipette solution contained (mM): $\mathrm{KCl}(0-135)$ or K-gluconate (0-135); $\mathrm{MgCl}_{2} 2 ; \mathrm{MgATP} 2$; HEPES/KOH 10; and BAPTA 1; pH 7.3, 300 mOsm. A combination of $\mathrm{K}$-gluconate and $\mathrm{KCl}$ at a constant $\mathrm{K}^{+}$concentration of $135 \mathrm{mM}$ were used for $\mathrm{Cl}^{-}$calibration of ClopHensor constructs with six different $\mathrm{Cl}^{-}$concentrations in the pipette solution $\left(\left[\mathrm{Cl}^{-}\right]_{p}\right): 4,10,20,60,100$, and $135 \mathrm{mM}$. Calibration curves were obtained by recording from 5-7 cells for each $\left[\mathrm{Cl}^{-}\right]_{p}$. The effectiveness of the cell dialysis and $\left[\mathrm{Cl}^{-}\right]_{i}$ established after whole-cell penetration were checked by measurement of the reversal potential for glycine-induced currents. Glycine was applied locally using Picospritzer II (General Valve Corporation, USA) with a pipette positioned close to the soma of the recorded cell at different holding potentials.

All reagents were obtained from Sigma unless otherwise specified.

\section{INTRACELLULAR pH CALIBRATION OF ClopHensor VARIANTS}

For $\mathrm{pH}$ calibration b-escin permabilization method was used (Waseem et al., 2010). In more detail, a range of HEPES-based extracellular solutions (150 mM K-Gluconate, $20 \mathrm{mM}$ HEPES, and $10 \mathrm{mM}$ D-glucose) with different $\mathrm{pH}$ values was created by adding HEPES powder for acidification of the solution or $1 \mathrm{M}$ $\mathrm{NaOH}$ for alkalization.

To increase the permeability of the cell membrane to ions, $80 \mu \mathrm{M} \beta$-escin (Sigma, St Louis, USA) was added to the bath solution. $\beta$-escin was dissolved in water and prepared freshly for each experiment. This suspension was stable for about $2 \mathrm{~h}$. The coverslip with cultured cells was placed into the recording chamber and superfused with escin-containing bath solution until cells become swollen, indicating the dissipation of ion gradients and coupled membrane potential in treated cells. The perfusing solution was then switched to the escin-free bath solution in order to avoid lysis of the cells. Thereafter, the fluorescence responses of ClopHensor constructs corresponding to specified $\mathrm{H}^{+}$concentrations inside the cell were registered.

\section{REAL-TIME FLUORESCENCE IMAGING}

Fluorescence images were acquired using a customized digital imaging microscope. Excitation of cells at various wavelengths was achieved using a Polychrome $\mathrm{V}$ monochromator (Till Photonics, Germany). Light intensity was attenuated using neutral density filters. Emission wavelengths were controlled using a Lambda 10-3 controller (Sutter Instrument Company, USA). Fluorescence was visualized using an upright microscope Axioskop (Zeiss, Germany) equipped with a $60 \times$ waterimmersion objective (n.a. 0.9; LumPlanFL, Olympus, USA). Fluorescent emitted light passed to a 16-bit digital camera
Andor iXon EM+ (Andor Technology PLC, Northern Ireland). Images were acquired on a computer via a DMA serial transfer. All peripheral hardware control, image acquisition and image processing were achieved using Andor iQ software (Andor Technology PLC). The average fluorescence intensity of each region of interest (ROI) was measured.

Cells expressing ClopHensor variants were excited at three wavelengths: 458 and $488 \mathrm{~nm}$ for $\mathrm{Cl}^{-} / \mathrm{pH}$-sensitive $\mathrm{E}^{2} \mathrm{GFP}$ excitation, and $545 \mathrm{~nm}$ for excitation of DsRed-monomer. Fluorescent signals were recorded using a dual-band GFP/DsRed 493/574 dichroic mirror (Semrock Inc., USA) and two emission filters: $535 \pm 15 \mathrm{~nm}$ for $\mathrm{E}^{2} \mathrm{GFP}$ emission and $632 \pm 30 \mathrm{~nm}$ for emission of DsRed-monomer (both Chroma Technology Corporation, USA). The emission filters were mounted into the Lambda $10^{-3}$ Filter wheel (Sutter Instruments Company, Novato, USA).

The duration of excitation at each wavelength was usually $20 \mathrm{~ms}$. The sampling interval was $5 \mathrm{~s}$ for the slow $\left[\mathrm{Cl}^{-}\right]_{i}$ changes during the transition of the recorded cell in whole-cell configuration and was switched to $1 \mathrm{~s}$ for the fast $\left[\mathrm{Cl}^{-}\right]_{i}$ transients in response to glycine application after establishing $\left[\mathrm{Cl}^{-}\right]_{i} /\left[\mathrm{Cl}^{-}\right]_{p}$ equilibrium.

\section{IMMUNOCYTOCHEMISTRY}

For immunodetection of constructs in $\mathrm{CHO}$ cells or hippocampal neurons, cells in culture on coverslips expressing ClopHensor or it derivatives were fixed in PFA $4 \%$ (wt/vol) in $0.1 \mathrm{M}$ phosphate buffer (PBS), pH 7.4, at room temperature for $15 \mathrm{~min}$. After fixation, the cells were rinsed three times in PBS. In each experimental procedure, control and experimental cells were processed together to eliminate potential bias due to inherent variations in the intensity of the immunohistochemical labeling. For further staining, neurons were pre-incubated in $4 \%(\mathrm{vol} / \mathrm{vol})$ normal goat serum in PBS containing $0.5 \%$ Triton X-100 (vol/vol) for $1 \mathrm{~h}$ at room temperature to block secondary-antibody binding sites. Coverslips with neurons expressing ClopHensor were then incubated overnight at $4^{\circ} \mathrm{C}$ with rabbit anti-GFP polyclonal antibody (Invitrogen) diluted 1:4000 in PBS with 4\% normal goat serum and mouse monoclonal anti-MAP2 antibodies (1:2000). Incubations with the primary antibodies were performed at room temperature and slow shaking for $1 \mathrm{~h}$, then overnight at $4^{\circ} \mathrm{C}$. Samples were rinsed three times in PBS. As secondary antibodies, either a Cy3-conjugated anti-rabbit IgG for detection of GFP or a Cy5-conjugated anti-mouse IgG for detection MAP2 (all 1:1500; Molecular Probes, Invitrogen) were used. Samples were then rinsed twice in PBS with one additional washing in PBS containing Hoechst 33342 (10 mg/ml; Sigma-Aldrich). Coverslips were mounted using Fluoromount ${ }^{\mathrm{TM}}$ (Sigma-Aldrich, St Louis, MO, USA).

Images were acquired using a Leica SP5C confocal microscope using 40-60× oil-immersion objectives. Micrographs shown here are digital composites of $Z$-series scans of 5-15 optical sections through a depth of 1-6 $\mu \mathrm{m}$. Final images were constructed with ImageJ software.

\section{In vitro ANALYSIS}

In vitro characterization of $\mathrm{H}^{+}$and $\mathrm{Cl}^{-}$-binding properties was performed by analysing fluorescence spectra variations with a 
multimodal plate reader (EnSpire; PerkinElmer) in 96-well plates. Acetic acid buffer $(50 \mathrm{mM})$ was used to adjust the solution $\mathrm{pH}$ to around 5.2, $100 \mathrm{mM}$ PBS was used for the $\mathrm{pH}$ range 5.2-8.0 and $20 \mathrm{mM}$ DEA buffer was used for the $\mathrm{pH}$ range 8.0-8.5. Temperature was kept constant at $20 \pm 0.5^{\circ} \mathrm{C}$ and fluorescence spectra were acquired with 1-nm steps. Protein concentration was always kept constant at about $1 \mu \mathrm{M}$ throughout every $\mathrm{pH}$ and $\mathrm{Cl}$ titration.

The proton dissociation constant $\left(\mathrm{p} K_{a}\right)$ was obtained by fitting fluorescence data with the equation:

$$
\mathrm{F}=\frac{A_{1}+A_{2} 10^{\left(\mathrm{p} K_{a}-\mathrm{pH}\right)}}{1+10\left(\mathrm{p} K_{a}-\mathrm{pH}\right)}
$$

which describes the effect of environmental proton concentration $(\mathrm{pH})$ on chromophore fluorescence $(F)$.

The chloride dissociation constant $\left(K_{d}^{C l}\right)$ was obtained by fitting data with a 1:1 Langmuir binding model (Arosio et al., 2007):

$$
S=\frac{S_{0}+S_{1} \cdot[C l] / K_{d}^{\mathrm{Cl}}}{1+[C l] / K_{d}^{\mathrm{Cl}}} .
$$

\section{RESULTS}

\section{DESCRIPTION OF THE CONSTRUCTS AND in vitro ANALYSIS}

In this study we performed calibration and functional characterization of the original ClopHensor and doubly palmitoylated membrane-targeted constructs (Arosio et al., 2010), as well as a new ClopHensor variant with mutations designed to increase $\mathrm{Cl}^{-}$ affinity and shift $\mathrm{p} K_{a}$ to more alkaline values (Figure 1B).

ClopHensor was designed by linking two fluorescent proteins, $\mathrm{E}^{2}$ GFP ? EGFP-T203Y and DsRed-monomer by means of a flexible 20-amino-acid spacer. To target the sensor to the inner interface of the plasma membrane, we inserted the N-terminal 20 residues of GAP-43, which contain two palmitoylation sites, at the ClopHensor N-terminus (Figure 1A). DsRed fluorescence, which is not affected by $\mathrm{pH}$ or $\mathrm{Cl}^{-}$changes, was shown to provide an excellent normalization signal leading to ratiometric $\mathrm{Cl}^{-}$sensing, free from the influence of sensor concentration in living neurons.

Following purification of the $E^{2}$ GFP-H148G-V224L mutant, $\mathrm{Cl}^{-}$-binding properties of the recombinant protein were investigated in vitro by measuring fluorescence spectra at constant $\mathrm{pH}$ and increasing $\mathrm{Cl}^{-}$concentration, from 0 to $310 \mathrm{mM}$ (Figures 2A,B). Because of the cooperative interaction between $\mathrm{Cl}^{-}$and $\mathrm{H}^{+}$binding, $\mathrm{Cl}^{-}$titrations were measured at various $\mathrm{pH}$ values (from 5.25 to 8.9 ) and $K_{d}$ values were analyzed with an infinite cooperative model (Arosio et al., 2007; Bregestovski and Arosio, 2011) with two interacting binding sites, one for $\mathrm{Cl}^{-}$and one for $\mathrm{H}^{+}$:

$$
K_{d}=\frac{K_{d}^{0} \cdot\left(1+10^{\left(\mathrm{p} K_{a}-\mathrm{pH}\right)}\right)}{10\left(\mathrm{p} K_{a}-\mathrm{pH}\right)}
$$

containing two fitting parameters for the probe: $\mathrm{p} K_{a}$ and $K_{d}^{0}$, the $\mathrm{Cl}^{-}$dissociation constant for the fully protonated form (present at $\mathrm{pH} \leq 5)$.

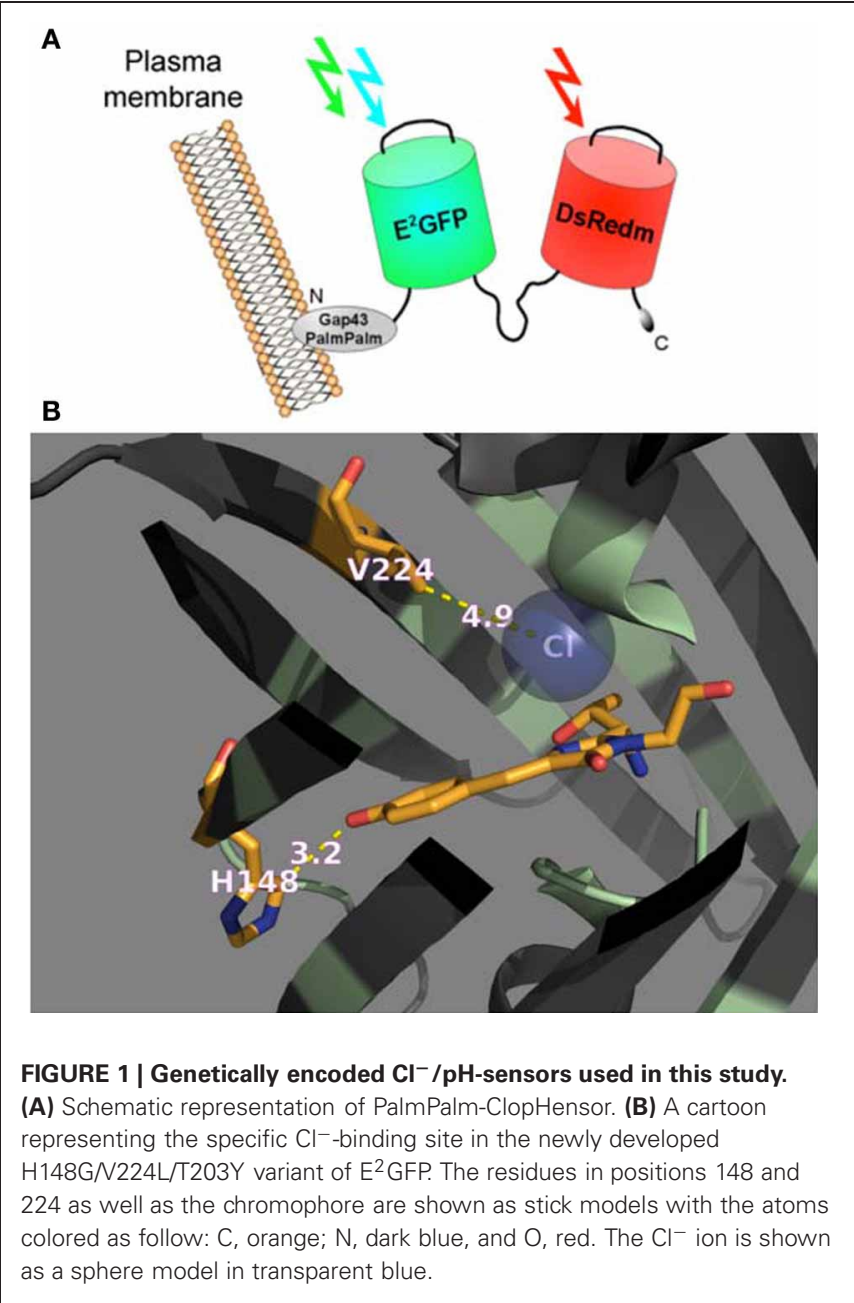

The proton binding equilibrium was studied and the $\mathrm{p} K_{a}$ value was determined from spectra acquired at different $\mathrm{pH}$ buffer conditions, ranging from 5.25 to 8.9 , in the absence of halogens (Figures 2C,D).

Precisely, the $\mathrm{Cl}^{-}$and $\mathrm{H}^{+}$binding thermodynamic parameters for $\mathrm{H} 148 \mathrm{G} / \mathrm{V} 224 \mathrm{~L}$ were found to be $\mathrm{p} K_{a}=7.9 \pm 0.05$ (best-fit \pm $\mathrm{SD})$ and $K_{d}^{0}=19 \pm 1.5 \mathrm{mM}$.

Overall, in vitro analysis at various $\mathrm{pH}$ and $\mathrm{Cl}^{-}$conditions revealed that the $\mathrm{H} 148 \mathrm{G} / \mathrm{V} 224 \mathrm{~L}$ mutant is suited for $\mathrm{Cl}^{-}$concentration measurements with reduced $\mathrm{pH}$ dependence in the physiological range. Indeed, in the $\mathrm{pH}$ range between 6.8 and 7.8 $K_{d}$ changes were between 18 and $30 \mathrm{mM}$ (Figure 3).

\section{DISTRIBUTION OF THE CONSTRUCTS IN CELLS}

To determine the intracellular distribution of ClopHensor constructs, we transiently expressed them in $\mathrm{CHO}$ cells and in neurons of dissociated hippocampal culture (see Materials and Methods). Expression was already observable $12 \mathrm{~h}$ after transfection and remained at high levels for at least 4 days. The fluorescence of the ClopHensor was distributed homogeneously throughout $\mathrm{CHO}$ cells (Figures $\mathbf{4 A , B}$, left) and in neurons (Figure 4C). The fluorescence was bright with no preferential 

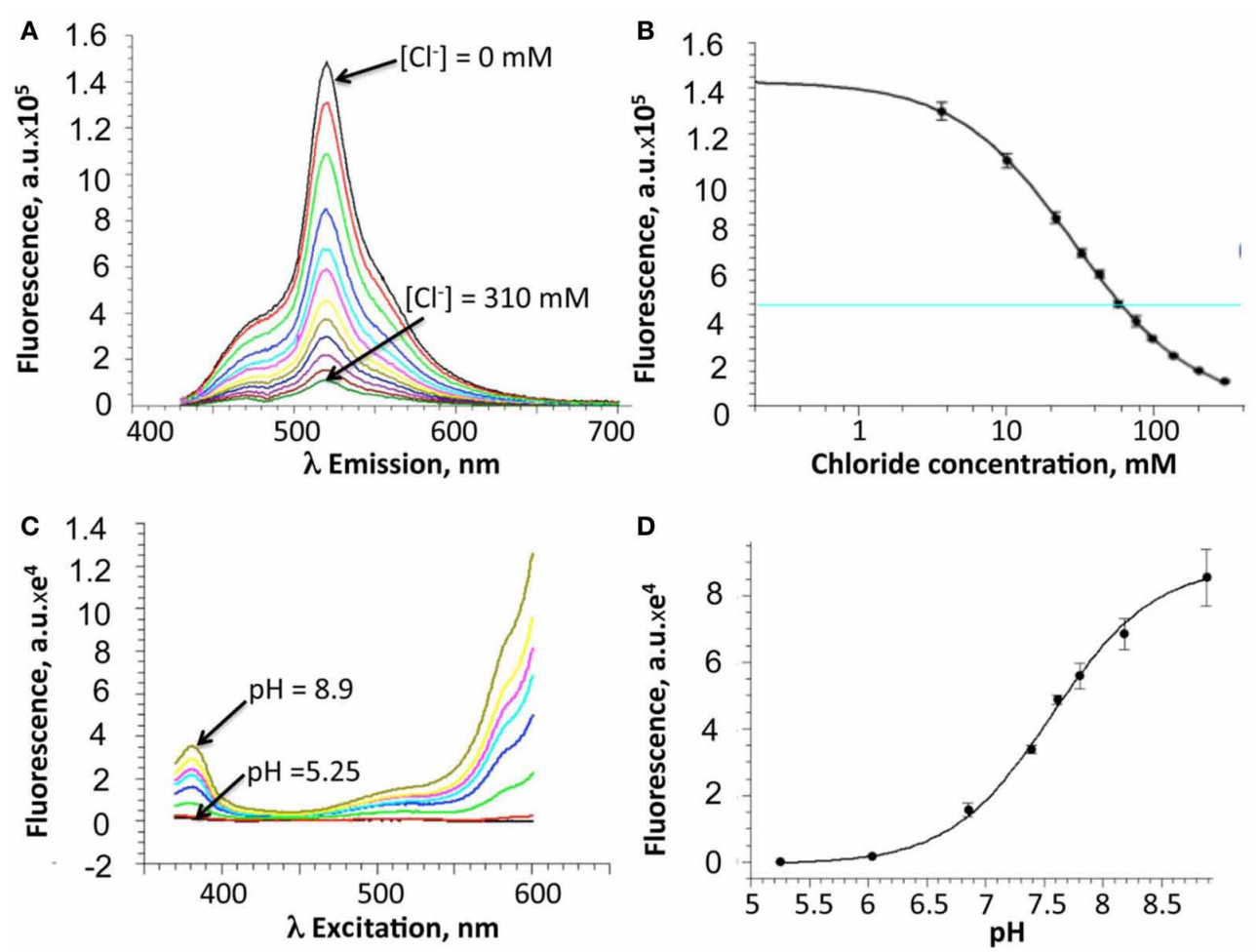

FIGURE 2 | In vitro properties of the H148G/V224L ClopHensor mutant. (A) Emission spectra at pH 7.0 for excitation at $415 \mathrm{~nm}$, at increasing $\mathrm{Cl}^{-}$ concentrations from $0 \mathrm{mM}$ (top spectrum) to $310 \mathrm{mM}$ (bottom spectrum). Note the reduction in fluorescence intensity due to $\mathrm{Cl}^{-}$binding-site quenching. (B) Dependence on $\mathrm{Cl}^{-}$concentration of the fluorescence intensity recorded at $520 \mathrm{~nm}$. (C) Excitation spectra, at different $\mathrm{pH}$ values, for emission at $520 \mathrm{~nm}$, in buffer without chloride. No isosbestic point is present. (D) $\mathrm{pH}$ dependence of the fluorescence intensity recorded at $485 \mathrm{~nm}$. For (B) and (D), data are represented as mean \pm SD from 3 independent measurements.

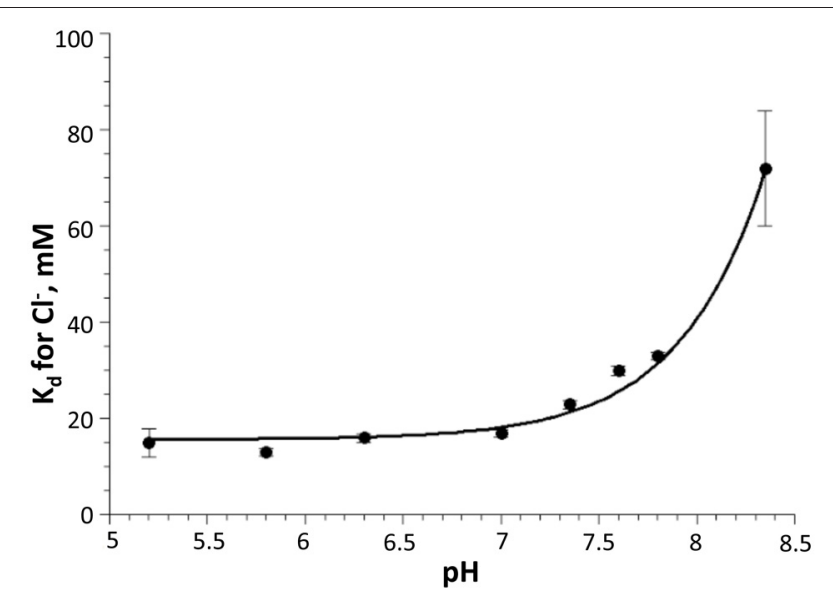

FIGURE 3 | Dependency of $\mathrm{Cl}^{-}$dissociation constant $K_{d}$ on pH for H148G/V224L mutant. Note the relatively small variations of $K_{d}$ in the physiological $\mathrm{pH}$ range (7.0-7.5). Data are represented as mean \pm SD from 3 independent measurements.

staining of membrane or intracellular organelles, as illustrated by the fluorescence profile (Figure 4B, left).

Distribution of the H148G/V224L mutant was also cytoplasmic, similar to those for ClopHensor (Figures 4A,B, middle).
In contrast, the PalmPalm-ClopHensor typically showed nearmembrane distribution; however, a small fraction of the probe could still be observed in the cytoplasm (Figures 4A,B, right).

These observations indicate that ClopHensor and H148G/V224L mutants exhibit cytoplasmic intracellular distributions while the PalmPalm-ClopHensor construct is typically localized to the plasma membrane and the Golgi region, as it was shown previously (McCabe and Berthiaume, 1999).

\section{INTRACELLULAR CALIBRATION OF THE CONSTRUCTS Calibration for $\mathrm{Cl}^{-}$}

In order to evaluate the dynamic range and sensitivity of constructs to ions, we co-expressed them in $\mathrm{CHO}$ cells with $\mathrm{Cl}^{-}$selective GlyR channels and performed simultaneous monitoring of whole-cell currents and fluorescent signals. Whole-cell recordings were performed with different $\mathrm{Cl}^{-}$concentrations in the pipette solution $\left(\left[\mathrm{Cl}^{-}\right]_{p}=4-135 \mathrm{mM}\right)$. To activate GlyR channels, glycine was applied using pressure pulses. For this, a pipette containing $200 \mu \mathrm{M}$ glycine dissolved in extracellular solution was advanced to within $30-50 \mu \mathrm{m}$ of the recorded cell (Figure 5A).

For ratiometric monitoring, following the approach presented in Arosio et al. (2010) we used the ratio $R_{C l}=F_{458} / F_{545}$ for measurement of intracellular $\mathrm{Cl}^{-}$concentration $\left(\left[\mathrm{Cl}^{-}\right]_{i}\right)$, and for calculating intracellular $\mathrm{pH}$ values $\left(\mathrm{pH}_{i}\right)$ the ratio $R_{p H}=$ $F_{488} / F_{458}$ was used. 


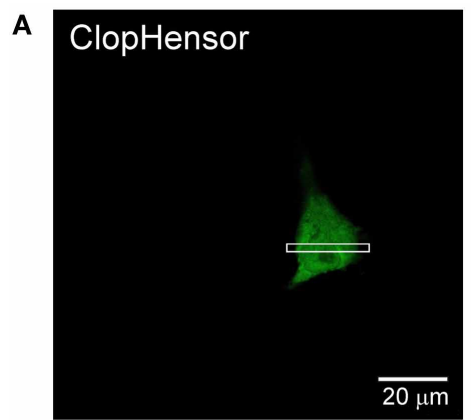

B ClopHensor

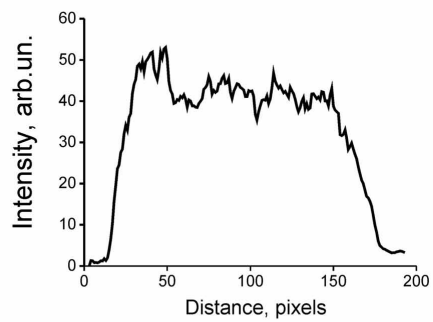

C

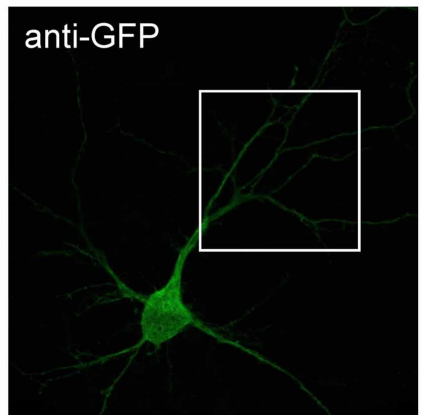

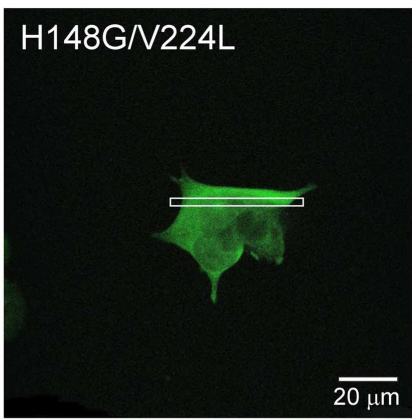

H148G/V224L
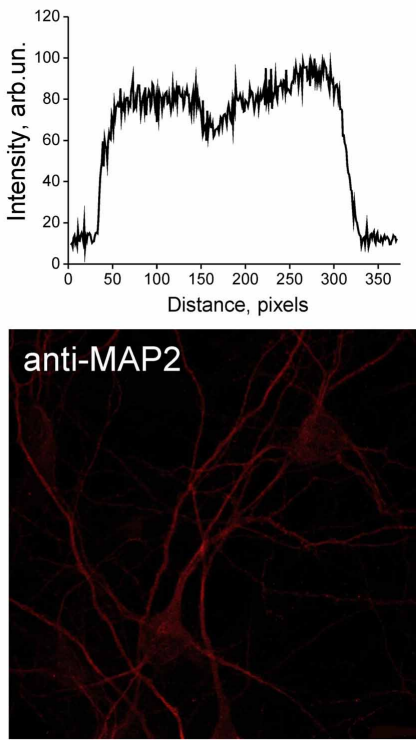

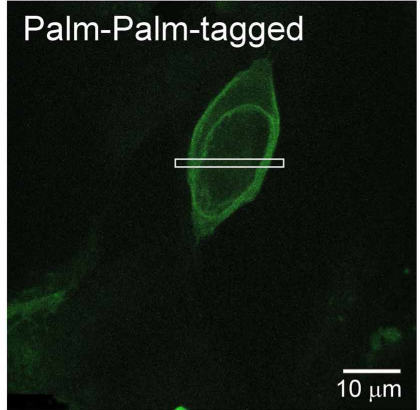

Palm-Palm-tagged
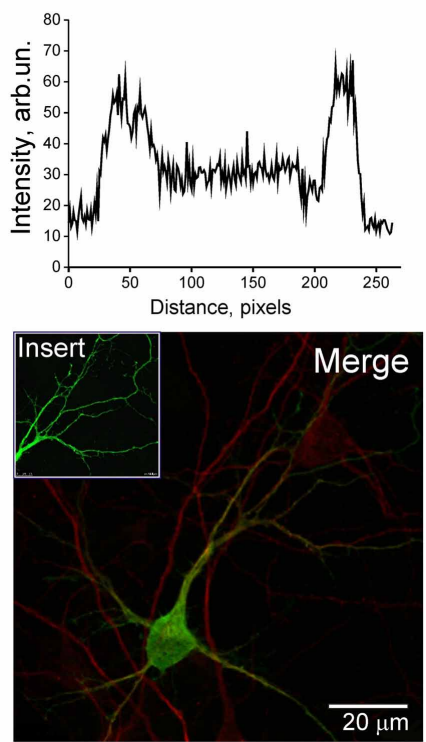

FIGURE 4 | Expression of ClopHensor and its derivatives in $\mathrm{CHO}$ cells and in hippocampal neurons. (A) Confocal micrographs of $\mathrm{CHO}$ cells expressing three genetically encoded probes and (B) illustrative profiles of signal intensity distribution within the corresponding selected area. Cells were transfected with ClopHensor (left), H148GN224L mutant (middle), and PalmPalm-ClopHensor (right). Note the difference in distribution patterns being predominantly cytoplasmic for both the
ClopHensor and H148GN224L mutant and preferential membrane localization for PalmPalm-ClopHensor that is additionally confirmed by profiles of fluorescent signal distribution. (C) Confocal micrographs of ClopHensor expressed in a hippocampal neuron (DIV14). The probe spread well throughout the cell body and processes, thus providing a suitable tool for $\left[\mathrm{Cl}^{-}\right]_{i}$ and $\mathrm{pH}_{i}$ monitoring in different regions of neurons.
Figure 5B illustrates relative changes in $\left[\mathrm{Cl}^{-}\right]_{i}$ during wholecell recordings from three cells, using pipettes with solutions containing different $\mathrm{Cl}^{-}$concentrations. The graph represents changes in $R_{C l} / R_{C l}$ with time, where $R_{C l_{0}}$ corresponds to $\left[\mathrm{Cl}^{-}\right]_{i}$ in the cell-attached mode, i.e., to the native concentration of $\mathrm{Cl}^{-}$ in the cytoplasm of $\mathrm{CHO}$ cells. Obtaining the whole-cell configuration by rupturing the membrane with a pipette containing $135 \mathrm{mM} \mathrm{Cl}^{-}$resulted in a strong decrease in $R_{C l} / R_{C l_{0}}$, corresponding to elevation of $\left[\mathrm{Cl}^{-}\right]_{i}$. In contrast, on rupture of the membrane with the pipette containing $4 \mathrm{mM} \mathrm{Cl}^{-}$an increase in $R_{C l} / R_{C l}$ was observed. Transition to the whole-cell configuration with a pipette containing $20 \mathrm{mM} \mathrm{Cl}^{-}$produced a short transient, increasing with stabilization of $R_{C l} / R_{C l}$ at a level close to those in the cell-attached configuration. This reflects the fact that in the recorded cell the native value of $\left[\mathrm{Cl}^{-}\right]_{i}$ in cytoplasm is close to the $\left[\mathrm{Cl}^{-}\right]_{p}$ of $20 \mathrm{mM}$.
Simultaneous monitoring of relative $\mathrm{pH}$ changes $\left(R_{p H} / R_{p H_{0}}\right)$ showed that after transition to the whole-cell configuration $\mathrm{pH}_{i}$ similarly decreased for all three cells recorded with different $\left[\mathrm{Cl}^{-}\right]_{p}$ but with identical $\mathrm{pH}$ (Figure 5C).

Calibration curves for $\mathrm{Cl}^{-}$obtained from six different $\left[\mathrm{Cl}^{-}\right]_{p}$ in physiological conditions were best fitted by a Logistic DoseResponse Sigmoidal Fit using the OriginPro 8.5 program with the formula:

$$
R_{\mathrm{Cl}}=A 2+\frac{A 1-A 2}{1+\left(\frac{\left[C l^{-}\right] i}{K_{d}}\right)^{p}}
$$

where $R_{C l}$ is the fluorescence ratio for $\mathrm{Cl}^{-}\left(F_{458} / F_{545}\right), K_{d}$ is the dissociation constant for $\mathrm{Cl}^{-}$binding, $\mathrm{A} 1$ and $\mathrm{A} 2$ are, respectively, the minimum and maximum asymptotic values of $R_{C l}$, and $p$ is the power value. 

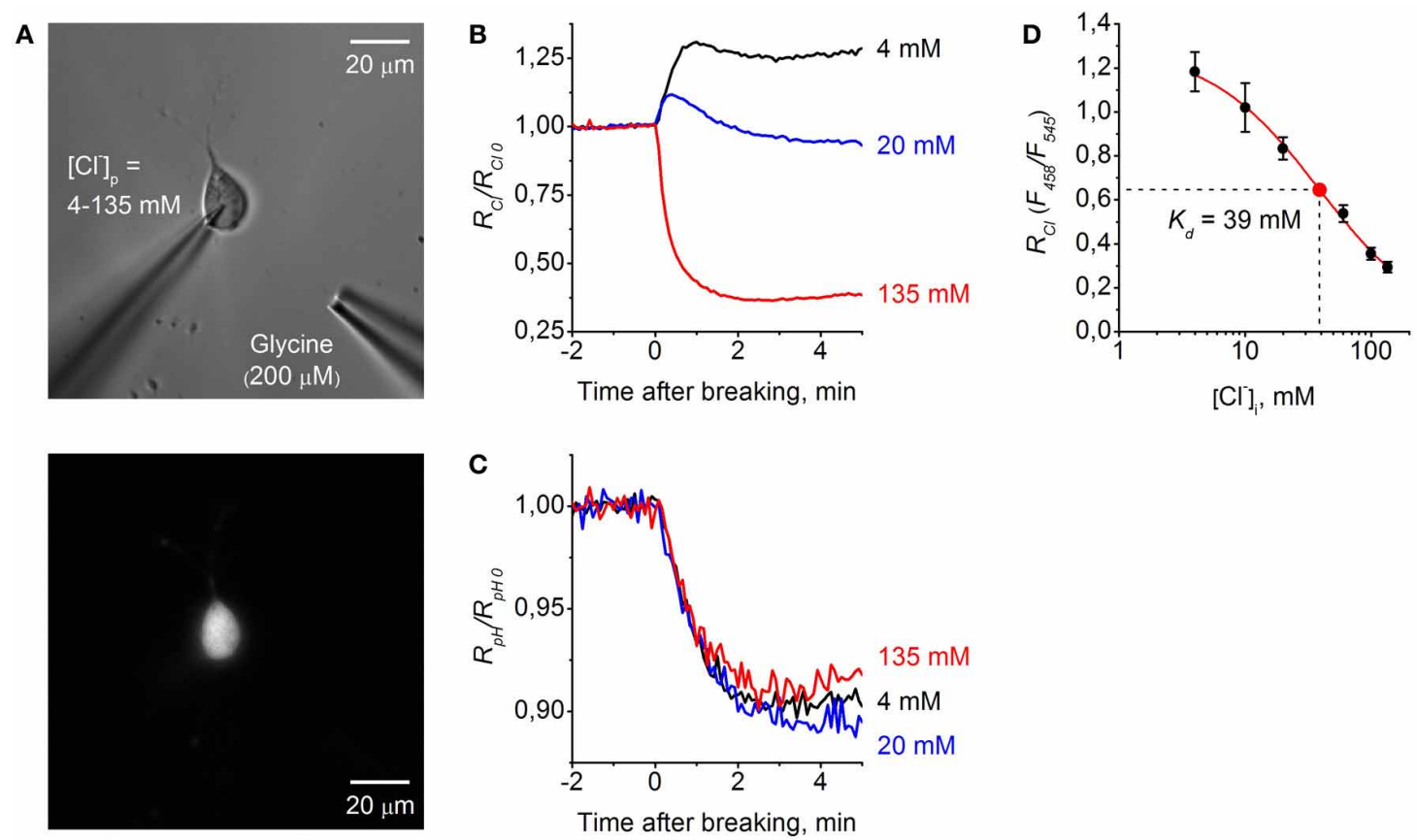

FIGURE 5 | Calibration of ClopHensor for $\mathrm{Cl}^{-}$. (A) Micrographs of $\mathrm{CHO}$ cell co-transfected by ClopHensor and GlyR taken with white light (top) and $545 \mathrm{~nm}$ excitation (bottom). Note the patch pipette on the cell and puff pipette for glycine application at about $50 \mu \mathrm{m}$ from the recorded cell. (B) Relative changes in $R_{C l}\left(F_{458} / F_{545}\right)$ measured in three cells during whole-cell recordings with different $\left[\mathrm{Cl}^{-}\right]_{p}: 4 \mathrm{mM}$ (black trace), $20 \mathrm{mM}$ (blue trace), and $135 \mathrm{mM}$ (red trace). Each trace represents data from a single cell. Time $=0$ corresponds to the moment the membrane breaks to give whole-cell mode. (C) Relative changes in $R_{p H}\left(F_{488} / F_{458}\right)$ recorded simultaneously in the same cells as in (B) before and after cells transition into the whole-cell configuration. (D) Calibration curve for ClopHensor obtained by recording of $R_{C l}$ at six different $\left[\mathrm{Cl}^{-}\right]_{p}: 4,10,20,60,100$, and $135 \mathrm{mM} . K_{d}=38.9 \pm 6.5 \mathrm{mM}$ (mean \pm s.e.m.). Data from 5-7 cells for each $\left[\mathrm{Cl}^{-}\right]_{p}$ are presented. Note the approximately four-fold change in $R_{C l}$ when $\left[\mathrm{Cl}^{-}\right]_{j}$ is adjusted from 4 to $135 \mathrm{mM}$.
From this formula we obtained the equation for $\left[\mathrm{Cl}^{-}\right]_{i}$ values recalculation:

$$
\left[C l^{-}\right]_{i}=K_{d} \cdot\left(\frac{A 1-A 2}{R_{\mathrm{Cl}}-A 2}-1\right)^{\frac{1}{p}}
$$

For ClopHensor the values of constants obtained from fitting the curve were the following: $K_{d}=38.9 \pm 6.5 \mathrm{mM}, \mathrm{A} 1=1.29, \mathrm{~A} 2=$ 0.01 , and $p=1$ (Figure 5D).

Similar analyses were performed for PalmPalm-ClopHensor and H148G/V224L mutants (Figure 6). They demonstrated that changes in $R_{C l} / R_{C l}$ observed at transitions from cell-attached to whole-cell configuration in cells expressing PalmPalmClopHensor were similar to those for ClopHensor (Figure 6A). From the calibration curve for PalmPalm-ClopHensor the following fitting parameters were obtained: $K_{d}=46.8 \pm 3.8 \mathrm{mM}$, $\mathrm{A} 1=1.15, \mathrm{~A} 2=0.29$, and $p=1.02$ (Figure 6B). While this value of $K_{d}$ was higher than for ClopHensor, the difference was non-significant $(P>0.05, t$-Student).

For cells expressing the $\mathrm{H} 148 \mathrm{G} / \mathrm{V} 224 \mathrm{~L}$ mutant, $\mathrm{R}_{\mathrm{Cl}} / R_{\mathrm{Cl}}$ when recording with the pipette containing $20 \mathrm{mM}^{-} \mathrm{Cl}^{-}$was almost midway between values recorded with pipettes containing 135 and $4 \mathrm{mM}$ (Figure 6C), suggesting higher sensitivity of the construct to $\mathrm{Cl}^{-}$. This was confirmed by obtaining the calibration curve for the H148G/V224L mutant. The constants were the following: $K_{d}=21.4 \pm 4.8 \mathrm{mM}, \mathrm{A} 1=1.58, \mathrm{~A} 2=1.06$, and $p=$
1.51 (Figure 6D). Statistical analysis of $K_{d}$ values for ClopHensor vs. H148G/V224L showed that they were significantly different $(P<0.05, t$-Student $)$ and for PalmPalm vs. H148G/V224L $K_{d}$ values were also significantly different $(P<0.01, t$-Student $)$. The dynamic range of $R_{C l}$ changes for the mutant was, however, smaller than those for the ClopHensor, which reduces the benefits arising from the increased affinity.

\section{Calibration for $\mathrm{pH}$}

As the H148G/V224L mutation caused a shift in the $\mathrm{p} K_{a}$, we performed comparative $\mathrm{pH}$ calibrations of ClopHensor and H148G/V224L mutant. For $\mathrm{pH}$ calibration, the $\beta$-escin method was used (see Materials and Methods).

Sequential exchanging of bath solutions with different $\mathrm{pH}$ values produced corresponding shifts in the fluorescence $\mathrm{pH}$ ratio (Figure 7).

For $\mathrm{pH}$ calibration curves a Dose-Response Sigmoidal Fit (OriginPro 8.5) with the following formula was used:

$$
R_{\mathrm{pH}}=B 1+\frac{B 2-B 1}{1+10^{\mathrm{p}\left(\mathrm{pK}_{a}-\mathrm{pH}_{\mathrm{i}}\right)}}
$$

where $R_{p H}$ is the fluorescence ratio for $\mathrm{pH}\left(F_{488} / F_{458}\right), \mathrm{p} K_{a}$ is the acid dissociation constant for $\mathrm{H}^{+}$binding, $\mathrm{B} 1$ and $\mathrm{B} 2$ are, respectively, the minimum and maximum asymptotic values of $R_{p H}$, and $p$ is the power value. 

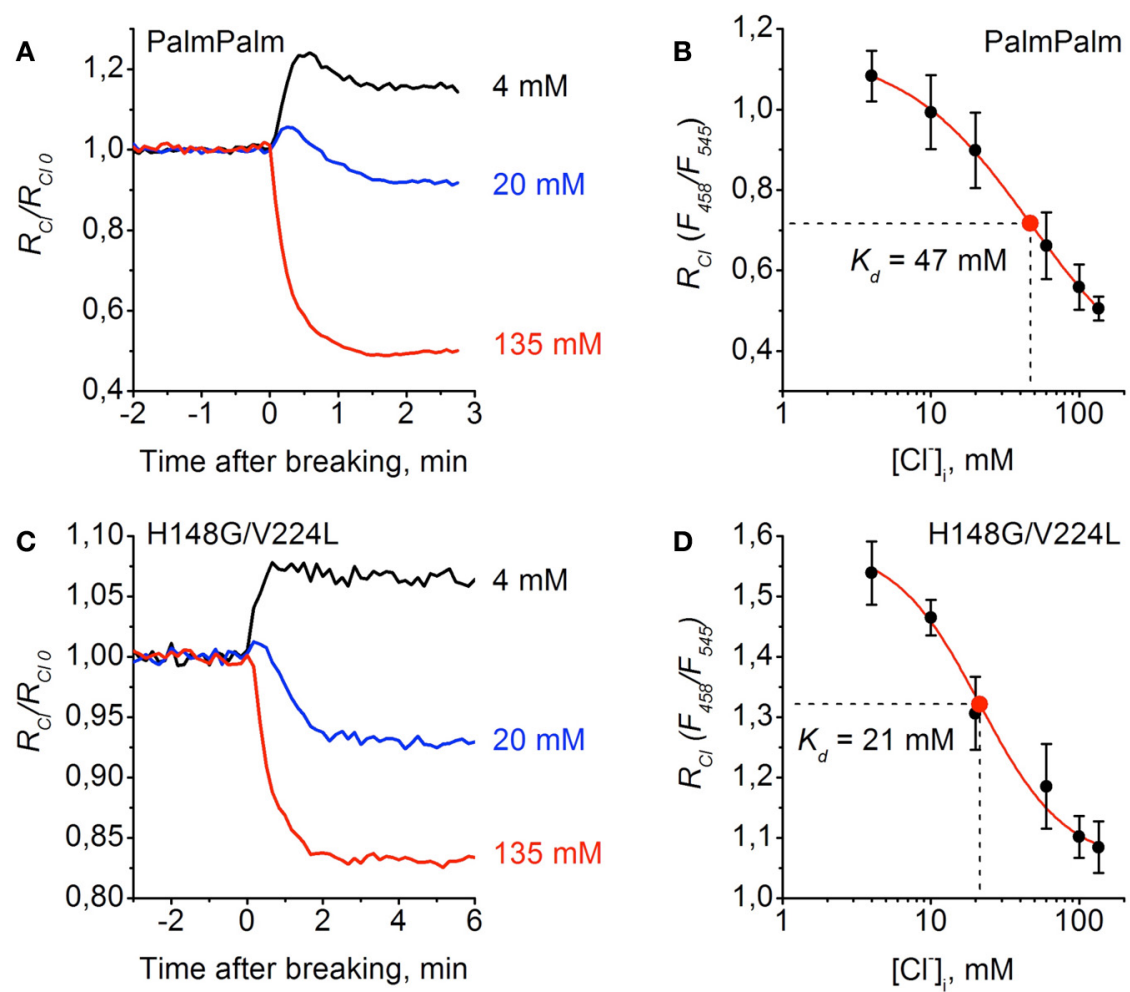

FIGURE 6 | Calibration of PalmPalm-ClopHensor and H148G/V224L mutant for $\mathrm{Cl}^{-}$. (A) and (C) Relative changes in $R_{C l}\left(F_{458} / F_{545}\right)$ of PalmPalm-ClopHensor (A) and the H148GN224L mutant (C) measured in three cells during whole-cell recordings with different $\left[\mathrm{Cl}^{-}\right]_{p}: 4 \mathrm{mM}$ (black trace), $20 \mathrm{mM}$ (blue trace), and $135 \mathrm{mM}$ (red trace). Each trace represents the data from a single cell. Time $=0$ corresponds to the moment the membrane breaks to give whole-cell mode. (B) and (D) Calibration curve for
PalmPalm-ClopHensor (B) and H148GN224L mutant (D) obtained by recording $R_{C l}$ at six different $\left[\mathrm{Cl}^{-}\right]_{p}: 4,10,20,60,100$, and $135 \mathrm{mM}$. For PalmPalm-ClopHensor $K_{d}=46.8 \pm 3.8 \mathrm{mM}$ and for H148GN224L mutant $K_{d}=21.4 \pm 4.8 \mathrm{mM}$. Data from 5-7 cells for each $\left[\mathrm{Cl}^{-}\right]_{p}$ are presented. Note the approximately two-fold changes in $R_{C l}$ for PalmPalm-ClopHensor when $\left[\mathrm{Cl}^{-}\right]_{i}$ changed from 4 to $135 \mathrm{mM}$ and the much smaller dynamic range of $R_{\mathrm{Cl}}$ for H148GN224L mutant.
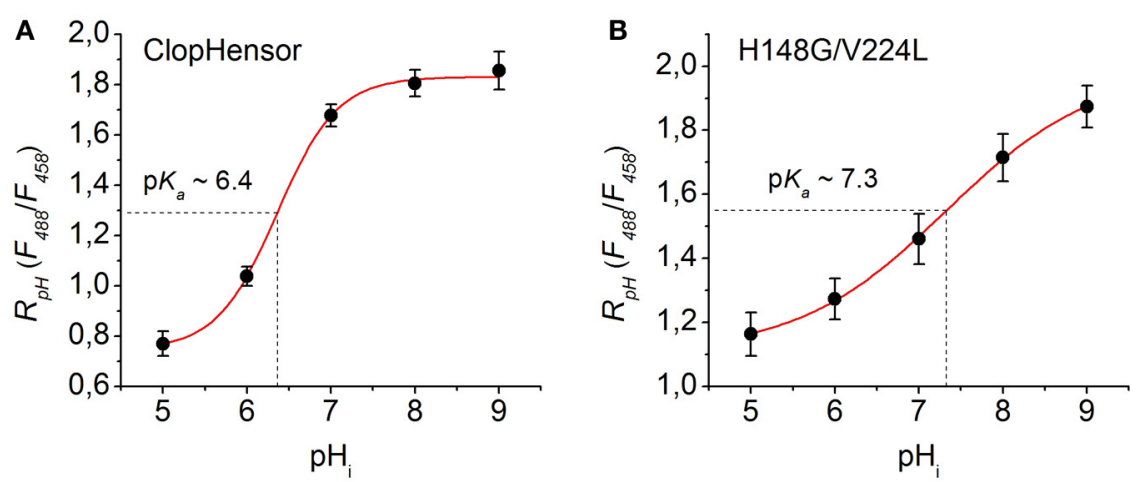

FIGURE 7 | Calibration of ClopHensor and H148G/V224L mutant for pH. (A) and (B) Changes in $R_{p H}\left(F_{488} / F_{458}\right)$ of $C l o p H e n s o r(A)$ and H148G/N224L mutant (B) measured in transfected partially permeabilized $\mathrm{CHO}$ cells perfused with bath medium of different $\mathrm{pH}$ values (see Materials and Methods for details).

From this formula we obtained the equation for $\mathrm{pH}_{i}$ values recalculation:

$$
\mathrm{pH}_{\mathrm{i}}=\mathrm{p} K_{a}-\frac{1}{\mathrm{p}} \cdot \log \left(\frac{B 2-B 1}{R_{\mathrm{pH}}-B 1}-1\right)
$$

Based on the fitting of the experimental curves the constants values obtained were: $\mathrm{p} K_{a}=6.36, \mathrm{~B} 1=0.75, \mathrm{~B} 2=1.83$, and $p=1.21$ for ClopHensor (Figure 7A) and $\mathrm{p} K_{a}=7.32, \mathrm{~B} 1=$ $1.11, \mathrm{~B} 2=1.99$, and $p=0.49$ for the H148G/V224L mutant (Figure 7B). In comparison with ClopHensor, the dynamic range 
of $R_{p H}$ changes and the slope of the calibration curve characterizing by the constant $p$ for the mutant were smaller, indicating its lower $\mathrm{pH}$ sensitivity.

\section{Transients of $\left[\mathrm{Cl}^{-}\right]_{i}$ and $\mathrm{pH}_{i}$ during activation glycine receptor channels}

We further performed comparative analysis of the three variants of ClopHensor while monitoring $\left[\mathrm{Cl}^{-}\right]_{i}$ and $\mathrm{pH}_{i}$ transients induced by activation of $\mathrm{Cl}^{-}$-selective GlyR channels in $\mathrm{CHO}$ cells.

Figure 8A illustrates changes in $\left[\mathrm{Cl}^{-}\right]_{i}$ monitored from three $\mathrm{CHO}$ cells co-expressing ClopHensor with GlyR and recorded with different $\left[\mathrm{Cl}^{-}\right]_{p}: 4 \mathrm{mM}$ (black trace), $20 \mathrm{mM}$ (blue trace), and $135 \mathrm{mM}$ (red trace). Values of $\left[\mathrm{Cl}^{-}\right]_{i}$ recalculated from $R_{C l}\left(F_{458} / F_{545}\right)$ were obtained using the calibration curve in Figure 5D. The transition to whole-cell configuration (holding potential $V_{h}=-30 \mathrm{mV}$ ) with a pipette containing $135 \mathrm{mM} \mathrm{Cl}^{-}$ caused a strong elevation of $\left[\mathrm{Cl}^{-}\right]_{i}$. After peaking, $\left[\mathrm{Cl}^{-}\right]_{i}$ slowly declined, presumably due to pumping out of $\mathrm{Cl}^{-}{ }_{i}$ by transporters (see, for instance, Pellegrino et al., 2011) or through weakly activated $\mathrm{Cl}^{-}$-selective ionic channels (Friedel et al., 2013). Application of $200 \mu \mathrm{M}$ glycine to the cell induced a transient decrease in $\left[\mathrm{Cl}^{-}\right]_{i}$, the amplitude of which depended on the duration of the applied pulses of the agonist and values of $V_{h}$. The holding potential was transiently changed to the values indicated on the figure for each pulse of glycine. Application of the agonist for $1 \mathrm{~s}$ caused a decrease of 5-10 mM, while activation of GlyRs for $10 \mathrm{~s}$ resulted in decrease of about $60 \mathrm{mM}$ (Figure 8A, red trace). After transiently diminishing, $\left[\mathrm{Cl}^{-}\right]_{i}$ recovered to its initial steady-state level. Interestingly, for the cell recorded with $\left[\mathrm{Cl}^{-}\right]_{p}=135 \mathrm{mM}$ it was difficult to increase $\left[\mathrm{Cl}^{-}\right]_{i}$ in conditions under which the glycine-induced current caused a strong influx of $\mathrm{Cl}^{-}$, i.e., at $V_{h}=+60$ and even at $+80 \mathrm{mV}$ (Figure 8A, asterisks, red trace). In this cell the reversal potential $\left(E_{r}\right)$ for $\mathrm{I}_{\text {Gly }}$ was about $+5 \mathrm{mV}$, as predicted for symmetric intracellularextracellular $\mathrm{Cl}^{-}$concentrations.

Simultaneous recording of $\left[\mathrm{Cl}^{-}\right]_{i}$ and ionic currents (Figure 8C) showed two main features. First, the kinetics of $\left[\mathrm{Cl}^{-}\right]_{i}$ transients were much slower than those for glycine-induced currents. This is in accordance with previous observations from monitoring of $\mathrm{Cl}^{-}$transients using MQAEmediated fluorescence (Marandi et al., 2002) or BioSensor-GlyR (Mukhtarov et al., 2008). Second, $\left[\mathrm{Cl}^{-}\right]_{i}$ amplitude increased both on elevation of the driving force for $\mathrm{Cl}^{-}$and on prolongation of glycine applications. As illustrated in Figure 8C, the amplitude of $\left[\mathrm{Cl}^{-}\right]_{i}$ transients induced by 1-s pulses of glycine increased in parallel with GlyR current amplitude at changes of $V_{h}$ from -20 to $0 \mathrm{mV}$. At constant $V_{h}(0 \mathrm{mV})$, prolongation of glycine pulses from 1 to $5 \mathrm{~s}$ caused an increase in $\left[\mathrm{Cl}^{-}\right]_{i}$ amplitude although an increase in GlyR current amplitude was not observed.

When transition to whole-cell configuration $\left(V_{h}=-20 \mathrm{mV}\right)$ was produced with a pipette containing $20 \mathrm{mM} \mathrm{Cl}^{-}$a brief transient decrease in $\left[\mathrm{Cl}^{-}\right]_{i}$ with subsequent stabilization at a level close to that in the cell-attached configuration was observed (Figure 8A, blue trace). Even at short $(100 \mathrm{~ms})$ glycine applications, substantial transients in $\left[\mathrm{Cl}^{-}\right]_{i}$, of about $5 \mathrm{mM}$, were

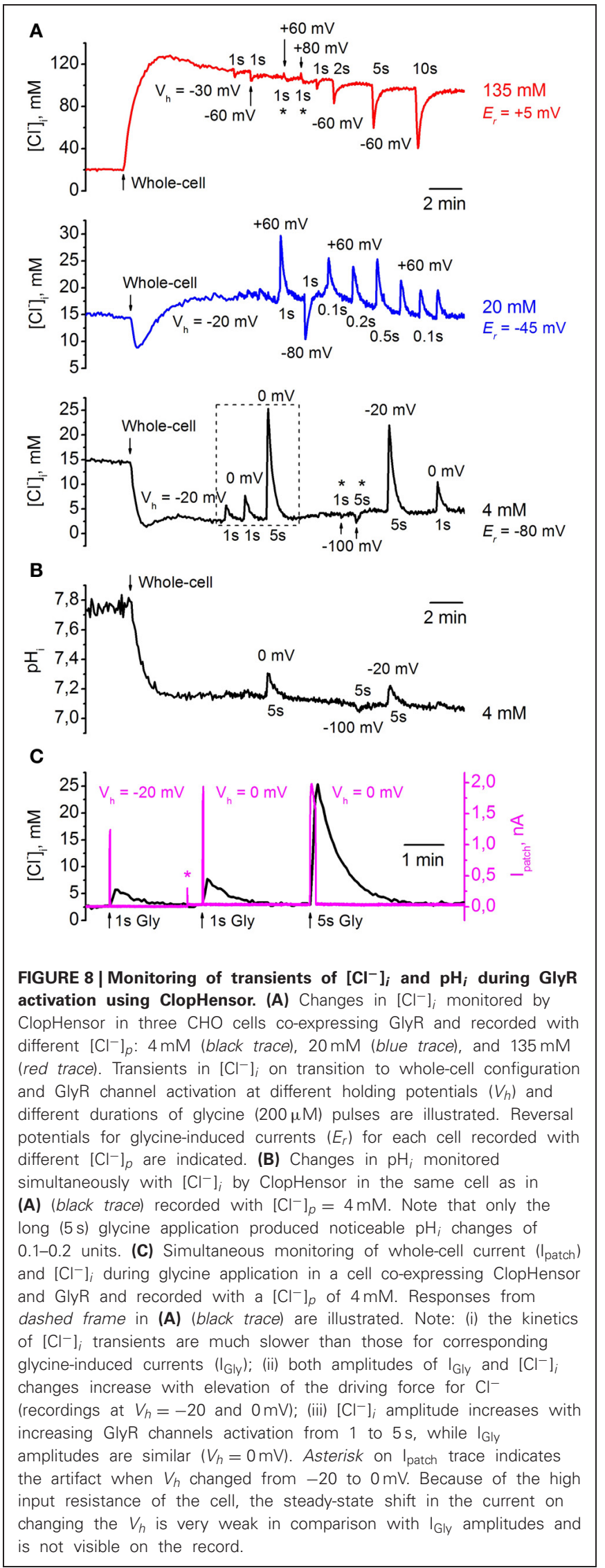

FIGURE 8 | Monitoring of transients of $\left[\mathrm{Cl}^{-}\right]_{i}$ and $\mathrm{pH}_{i}$ during GlyR activation using ClopHensor. (A) Changes in $\left.\mathrm{Cl}^{-}\right]_{i}$ monitored by ClopHensor in three $\mathrm{CHO}$ cells co-expressing GlyR and recorded with different $\left[\mathrm{Cl}^{-}\right]_{p}: 4 \mathrm{mM}$ (black trace), $20 \mathrm{mM}$ (b/ue trace), and $135 \mathrm{mM}$ (red trace). Transients in $\left[\mathrm{Cl}^{-}\right]_{i}$ on transition to whole-cell configuration and GlyR channel activation at different holding potentials $\left(V_{h}\right)$ and different durations of glycine $(200 \mu \mathrm{M})$ pulses are illustrated. Reversal potentials for glycine-induced currents $\left(E_{r}\right)$ for each cell recorded with different $\left[\mathrm{Cl}^{-}\right]_{p}$ are indicated. (B) Changes in $\mathrm{pH}_{i}$ monitored simultaneously with $\left[\mathrm{Cl}^{-}\right]_{i}$ by ClopHensor in the same cell as in (A) (black trace) recorded with $\left[\mathrm{Cl}^{-}\right]_{p}=4 \mathrm{mM}$. Note that only the long $(5 \mathrm{~s})$ glycine application produced noticeable $\mathrm{pH}_{i}$ changes of and $\left[\mathrm{Cl}^{-}\right]_{i}$ during glycine application in a cell co-expressing ClopHensor and GlyR and recorded with a $\left[\mathrm{Cl}^{-}\right]_{p}$ of $4 \mathrm{mM}$. Responses from dashed frame in (A) (black trace) are illustrated. Note: (i) the kinetics of $\left[\mathrm{Cl}^{-}\right]_{i}$ transients are much slower than those for corresponding glycine-induced currents $\left(I_{G \mid y}\right)$; (ii) both amplitudes of $I_{G l y}$ and $\left[\mathrm{Cl}^{-}\right]_{i}$ changes increase with elevation of the driving force for $\mathrm{Cl}^{-}$

(recordings at $V_{h}=-20$ and $0 \mathrm{mV}$ ); (iii) $\left[\mathrm{Cl}^{-}\right]_{i}$ amplitude increases with increasing GlyR channels activation from 1 to $5 \mathrm{~s}$, while $\mathrm{I}_{\mathrm{Gly}}$ a plitudes are similar $\left(V_{h}=0 \mathrm{mV}\right)$. Asterisk on I patch trace indicates input resistance of the cell, the steady-state shift in the current on changing the $V_{h}$ is very weak in comparison with $I_{G l y}$ amplitudes and is not visible on the record. 
recorded with $V_{h}=+60 \mathrm{mV}$; these reversed in direction when $V_{h}$ was changed from +60 to $-80 \mathrm{mV}$. $E_{r}$ for glycine-induced currents in this cell was about $-45 \mathrm{mV}$ (Figure 8A, blue trace).

With a pipette containing $4 \mathrm{mM} \mathrm{Cl}^{-}$, transition to whole-cell configuration $\left(V_{h}=-20 \mathrm{mV}\right)$, as predicted, caused a decrease in $\left[\mathrm{Cl}^{-}\right]_{i}$ (Figure 8A, black trace). At $V_{h}=-20$ and $0 \mathrm{mV}$, application of $200 \mu \mathrm{M}$ glycine induced strong $\left[\mathrm{Cl}^{-}\right]_{i}$ transients whose amplitudes increased with prolongation of pulse duration; these increases were about 3-5 and $18-22 \mathrm{mM}$ for glycine pulses of 1 and $5 \mathrm{~s}$, respectively. Similarly to high $\left[\mathrm{Cl}^{-}\right]_{p}$, for the cell recorded with a $\left[\mathrm{Cl}^{-}\right]_{p}$ of $4 \mathrm{mM}$ it was difficult to decrease $\left[\mathrm{Cl}^{-}\right]_{i}$ in conditions under which glycine-induced current caused efflux of $\mathrm{Cl}^{-}$, i.e., at $V_{h}=-100 \mathrm{mV}$ (Figure 8A, asterisks, black trace). $E_{r}$ for glycine-induced currents in this cell was about $-80 \mathrm{mV}$.

Simultaneous monitoring of $\mathrm{pH}_{i}$ in the same cell as that shown in Figure 8A, black trace, demonstrated a decrease in $\mathrm{pH}_{i}$ of about 0.6 units after transition to whole-cell configuration (Figure 8B). Values of $\mathrm{pH}_{i}$ recalculated from $R_{p H}\left(F_{488} / F_{458}\right)$ were obtained using the calibration curve in Figure 7A. The changes in $\left[\mathrm{Cl}^{-}\right]_{i}$ up to $5 \mathrm{mM}$ (with 1-s glycine applications) did not produce marked changes in $\mathrm{pH}_{i}$, while the changes in $\left[\mathrm{Cl}^{-}\right]_{i}$ to $\geq 20 \mathrm{mM}$ (with 5 -s glycine applications) caused changes in $\mathrm{pH}_{i}$ of $0.1-0.2$ units (Figure 8B).

These observations indicate that ClopHensor is a reliable tool for long-lasting simultaneous monitoring of intracellular $\mathrm{Cl}^{-}$and $\mathrm{pH}$ in living cells.

Next we analysed the properties of ClopHensor derivatives: the membrane-targeted PalmPalm-ClopHensor and the H148G/V224L ClopHensor mutant.

Figure 9A illustrates simultaneous monitoring of $\left[\mathrm{Cl}^{-}\right]_{i}$ (top trace) and $\mathrm{pH}_{i}$ (bottom trace) by PalmPalm-ClopHensor in $\mathrm{CHO}$ cells co-expressing GlyR and recorded with a $\left[\mathrm{Cl}^{-}\right]_{p}$ of $4 \mathrm{mM}$. Values of $\left[\mathrm{Cl}^{-}\right]_{i}$ recalculated from $R_{C l}\left(F_{545} / F_{458}\right)$ were obtained using the calibration curve in Figure 6B. The transition to wholecell configuration $\left(V_{h}=-20 \mathrm{mV}\right)$ produced a decrease in $\left[\mathrm{Cl}^{-}\right]_{i}$ similar to those monitored by ClopHensor. Short (100 ms) application of $200 \mu \mathrm{M}$ glycine to the cell induced transient increases in $\left[\mathrm{Cl}^{-}\right]_{i}$ that were dependent on the difference between the holding potential and the reversal potential of glycine-induced currents.

Transients in $\left[\mathrm{Cl}^{-}\right]_{i}$ varied from about $10 \mathrm{mM}$ at $V_{h}=0 \mathrm{mV}$ to about $20 \mathrm{mM}$ at $V_{h}=+60 \mathrm{mV}$ (Figure 9A, top trace). $E_{r}$ for glycine-induced currents in this cell was about $-75 \mathrm{mV}$. These changes were much higher than would be found when monitoring with ClopHensor at similar stimuli. This was confirmed on analysis of $\left[\mathrm{Cl}^{-}\right]_{i}$ transients when recording from cells expressing these two sensors. As illustrated in Figure 9B, very similar GlyR currents induced $\left[\mathrm{Cl}^{-}\right]_{i}$ transients whose amplitude appeared about 2.5-fold higher when monitored by PalmPalm-ClopHensor.

As the molecular organization of PalmPalm-ClopHensor is identical to that of ClopHensor, the recalculation of $\mathrm{pH}_{i}$ values from $R_{p H}\left(F_{488} / F_{458}\right)$ was done using the calibration curve in Figure 7A. Similarly, after transition to whole-cell configuration, $\mathrm{pH}_{i}$ decreased by about 0.5 units (Figure 9A, bottom trace). Very weak $\mathrm{pH}_{i}$ transients were observed (Figure 9A, bottom trace) with short $(100 \mathrm{~ms})$ glycine applications even at $V_{h}=+60 \mathrm{mV}$, while the transient increase in $\left[\mathrm{Cl}^{-}\right]_{i}$ in this cell was about $20 \mathrm{mM}$ (Figure 9A, top trace).
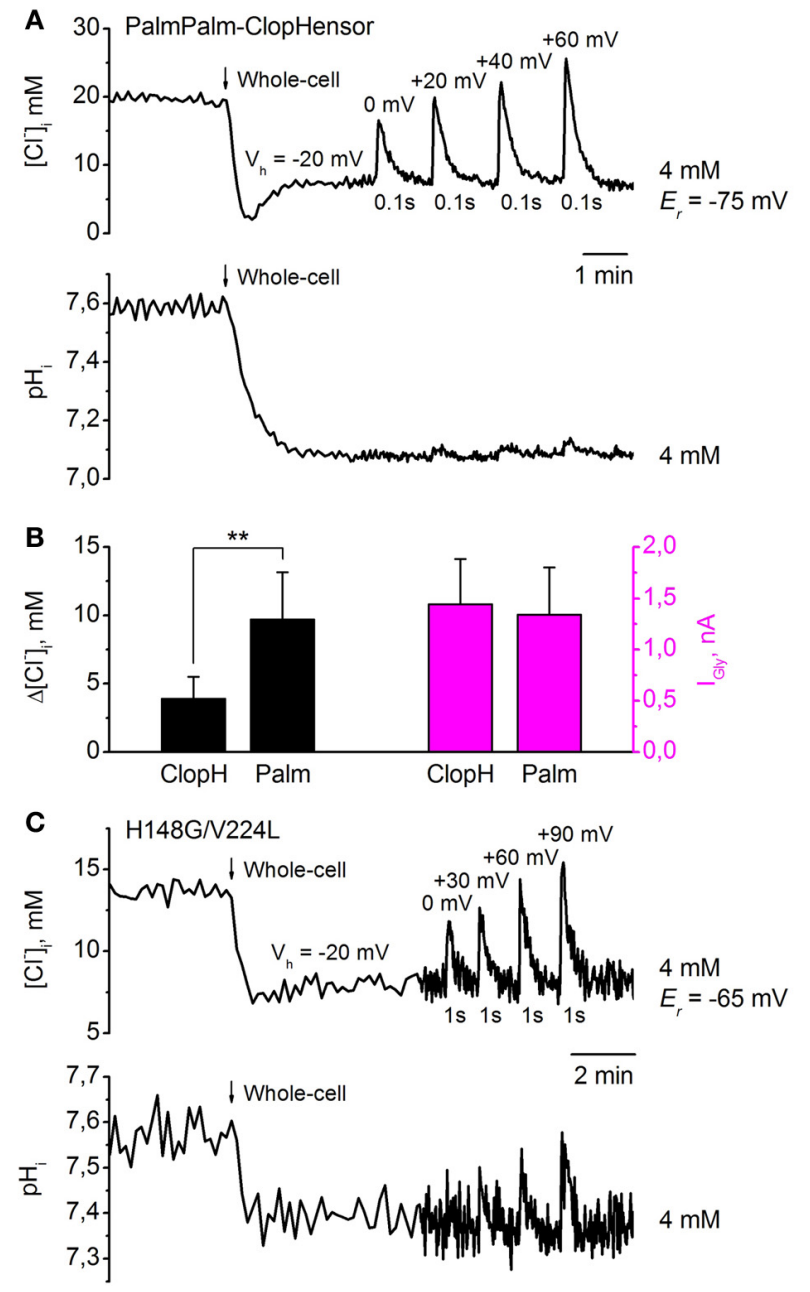

FIGURE 9 | Monitoring of transients in $\left[\mathrm{Cl}^{-}\right]_{i}$ and $\mathrm{pH}_{i}$ in response to GlyR activation, using PalmPalm-ClopHensor and the H148G/V224L mutant. (A) Changes in $\left[\mathrm{Cl}^{-}\right]_{i}$ (top trace) and $\mathrm{pH}_{i}$ (bottom trace) monitored simultaneously by PalmPalm-ClopHensor in a $\mathrm{CHO}$ cell co-expressing GlyR and recorded with $\left[\mathrm{Cl}^{-}\right]_{p}=4 \mathrm{mM}$. Transients in $\left[\mathrm{Cl}^{-}\right]_{i}$ and $\mathrm{pH}_{i}$ upon whole-cell penetration and GlyR activation by pressure application of $200 \mu \mathrm{M}$ glycine to the cell at different $V_{h}$ and $100 \mathrm{~ms}$ duration of agonist application are illustrated. The reversal potential for glycine-induced currents $\left(E_{r}\right)$ is indicated. Note the very small $\mathrm{pH}_{i}$ changes at short $(100 \mathrm{~ms})$ glycine application (bottom trace). (B) Averaged glycine-induced current $\left(\mathrm{I}_{\mathrm{Gly}}\right)$ amplitudes (magenta columns, right) and corresponding $\left[\mathrm{Cl}^{-}\right]_{i}$ changes (black columns, left) in response to 1-s glycine applications. Whole-cell recordings from $\mathrm{CHO}$ cells with pipettes containing $\left[\mathrm{Cl}^{-}\right]_{p}=4 \mathrm{mM}$. Cells expressed either ClopHensor $(\mathrm{ClopH})$ or PalmPalm-ClopHensor (Palm). Note that for very similar $I_{G l y}$, transients of $\left[\mathrm{Cl}^{-}\right]_{i}$ are about 2.5-fold higher when monitored by PalmPalm-ClopHensor than by ClopHensor. Data from seven cells for each sensor are illustrated. ${ }^{* *} P<0.01$ (ANOVA). (C) Changes in $\left[\mathrm{Cl}^{-}\right]_{i}$ (top trace) and $\mathrm{pH}_{i}$ (bottom trace) monitored by the H148GN224L mutant of ClopHensor in a $\mathrm{CHO}$ cell co-expressing GlyR and recorded with a $\left[\mathrm{Cl}^{-}\right]_{p}$ of $4 \mathrm{mM}$. Transients in $\left[\mathrm{Cl}^{-}\right]_{i}$ upon whole-cell penetration and GlyR activation by pressure application of $200 \mu \mathrm{M}$ glycine to the cell at different $V_{h}$ and 1-s duration of agonist application are illustrated. Note the evident $\mathrm{pH}_{i}$ changes of about 0.1 units only under conditions of substantial difference between $V_{h}$ and $E_{r}$ and relatively long (1-s) glycine application. Different baseline noise in the two traces resulted from changes in acquisition frequency from 0.2 to $1 \mathrm{~Hz}$. 
When the H148G/V224L mutant of ClopHensor was coexpressed with GlyR in CHO cells recorded with $\left[\mathrm{Cl}^{-}\right]_{p}=4 \mathrm{mM}$, a decrease in $\left[\mathrm{Cl}^{-}\right]_{i}$ on transition to whole-cell configuration ( $V_{h}=-20 \mathrm{mV}$ ) was also observed (Figure 9C, top trace). Values of $\left[\mathrm{Cl}^{-}\right]_{i}$ recalculated from $R_{C l}\left(F_{545} / F_{458}\right)$ were obtained using the calibration curve in Figure 6D. Again, glycine-induced transient increases in $\left[\mathrm{Cl}^{-}\right]_{i}$ depended on the difference between $\mathrm{V}_{h}$ and $E_{r}$. Transients in $\left[\mathrm{Cl}^{-}\right]_{i}$ with 1 -s glycine application varied from about $5 \mathrm{mM}$ at $V_{h}=0 \mathrm{mV}$ to about $10 \mathrm{mM}$ at $V_{h}=$ $+90 \mathrm{mV}$. $E_{r}$ for glycine-induced currents in this cell was about $-65 \mathrm{mV}$.

Simultaneous monitoring of $\mathrm{pH}_{i}$ in the same cell reveal that the $\left[\mathrm{Cl}^{-}\right]_{i}$ transients below $5 \mathrm{mM}$ did not produce marked changes in $\mathrm{pH}_{i}$. The recalculation of $\mathrm{pH}_{i}$ values from $R_{p H}\left(F_{488} / F_{458}\right)$ was done using the calibration curve in Figure 7B. An evident $\mathrm{pH}_{i}$ increase (of about 0.1 units) was recorded only when there was a substantial difference between $V_{h}$ and $E_{r}$ and relatively long (1-s) glycine application, which induced a $\left[\mathrm{Cl}^{-}\right]_{i}$ elevation of about $10 \mathrm{mM}$ (Figure 9C, bottom trace).

These results demonstrate that PalmPalm-ClopHensor, which has preferable membrane targeting, could be of interest for nearmembrane measurement of intracellular $\mathrm{Cl}^{-}$and $\mathrm{pH}$ changes. Another construct, the H148G/V224L mutant of ClopHensor, with a higher affinity for $\mathrm{Cl}^{-}$, possesses the smallest dynamic range of $R_{C l}\left(F_{458} / F_{545}\right)$ changes and this could be a limiting factor in some cases due to lower signal/noise ratio.

\section{DISCUSSION}

Development of genetically encoded probes for non-invasive monitoring of ions and protein function has opened powerful routes for the analysis of a variety of physiological problems and functions of various cell types under different experimental conditions. These probes are non-toxic, capable of remaining stable in cells for a long time, can be expressed in specific cellular compartments and are suitable for production of transgenic models.

Here, we describe the calibration in living cells, the cytoplasmic distribution, and examples of simultaneous monitoring of intracellular $\mathrm{Cl}^{-}$and $\mathrm{H}^{+}$of three genetically encoded sensors: (1) ClopHensor; (2) its variant designed to have preferential membrane targeting due to the addition to the N-terminus of a short peptide containing two palmitoylation sites (PalmPalmClopHensor) (Arosio et al., 2010), and (3) ClopHensor containing mutations of $\mathrm{E}^{2} \mathrm{GFP}$ (H148G/V224L) aimed at increasing the $\mathrm{Cl}^{-}$affinity of the sensor.

Following transient expression in $\mathrm{CHO}$ cells, ClopHensor and the H148G/V224L mutant exhibit cytoplasmic intracellular distribution while the PalmPalm-ClopHensor construct, as expected, is preferentially localized in the vicinity of membranes. Upon transfection of rat dissociated hippocampal cultures with cDNA of ClopHensor, the probe shows a strong cytoplasmically distributed fluorescence in the soma and neuronal processes. These observations indicate that all three sensors can be easily expressed in various cell types and detected in different, even very small, areas of cells.

Calibration analysis performed on $\mathrm{CHO}$ cells using patch pipettes containing different concentrations of $\mathrm{Cl}^{-}$, and also $\beta$-escin permeabilization with bath medium having different $\mathrm{pH}$ (Waseem et al., 2010) revealed that the constructs exhibit different sensitivity to $\mathrm{Cl}^{-}$and $\mathrm{H}^{+}$. While ClopHensor and PalmPalm-ClopHensor probes demonstrated $K_{d}$ for $\mathrm{Cl}^{-}$ of about $40 \mathrm{mM}$, for the H148G/V224L mutant this value was about $20 \mathrm{mM}$, indicating its higher affinity. However, the mutant exhibits a smaller dynamic range of $R_{C l}$, which could be a limiting factor for monitoring $\mathrm{Cl}^{-}$in cells containing low $\left[\mathrm{Cl}^{-}\right]_{i}$ or with small changes in $\mathrm{Cl}^{-}$concentration. Poor dynamic range could be, at least partially, explained by different spectral properties of H148G/V224L mutant (Figures 2A,C) from those for ClopHensor (Arosio et al., 2010). In the present study, for all constructs including the H148G/V224L mutant, the calibration measurements were performed using the same excitation wavelengths, GFP/DsRed dichroic mirror and emission filters (see Materials and Methods). We suggest that this range can be considerably extended in the future by better selection of excitation and emission parameters.

Calibration of $\mathrm{pH}$ in $\mathrm{CHO}$ cells using the $\beta$-escin method showed that the $\mathrm{p} K_{a}$ for the H148G/V224L mutant is strongly shifted to alkaline values. This is consistent with in vitro measurements: $\mathrm{p} K_{a}=7.9 \pm 0.05$. In vitro analysis also demonstrated that $K_{d}$ for $\mathrm{Cl}^{-}$of the $\mathrm{H} 148 \mathrm{G} / \mathrm{V} 224 \mathrm{~L}$ mutant exhibits relatively small $\mathrm{pH}$ dependency over a wide $\mathrm{pH}$ range: from about $18 \mathrm{mM}$ at $\mathrm{pH} 6.5$ to about $30 \mathrm{mM}$ at $\mathrm{pH} 7.8$. This suggests that the H148G/V224L mutant is a useful tool for $\left[\mathrm{Cl}^{-}\right]_{i}$ measurements in experimental models with high $\mathrm{pH}$ variations.

Our previous observations demonstrated that when using the CFP/YFP-based Cl-Sensor, long or frequent acquisition causes strong "bleaching" of $\mathrm{Cl}^{-}$-sensitive YFP resulting in changes in fluorescence parameters during ratiometric measurement of $\left[\mathrm{Cl}^{-}\right]_{i}$. This problem is discussed in detail in the paper by Friedel et al. (2013, this issue). In contrast, E²GFP-DsRedm-based ClopHsensor exhibits remarkable stability (see, for instance, Figures 8, 9), providing an excellent tool for long-lasting reliable monitoring and with variable acquisition rate.

Our observations of the effects of activation of $\mathrm{Cl}^{-}$selective GlyR channels on $\left[\mathrm{Cl}^{-}\right]_{i}$ indicate that it is a highly dynamic parameter, which can be strongly changed by overactivation of $\mathrm{Cl}^{-}$-selective channels or activity of other proteins involved in regulation and determination of physiological $\left[\mathrm{Cl}^{-}\right]_{i}$ in living systems. Indeed, activation of GlyRs for several seconds caused changes in $\left[\mathrm{Cl}^{-}\right]_{i}$ of more than $10-20 \mathrm{mM}$ (Figures 8, 9).

Together our experiments demonstrate that these three ClopHensor constructs are suitable tools for stable, long-lasting, non-invasive monitoring of $\left[\mathrm{Cl}^{-}\right]_{i}$ and $\mathrm{pH}_{i}$ in different cell types.

\section{ACKNOWLEDGMENTS}

We are grateful to Dr. Paul A. Heppenstal for critical reading of the manuscript. This study was supported for M. Mukhtarov by the European Union Seventh Framework Programme under grant agreement no. HEALTH-F2-2008-202088 ("Neurocypres" Project), for L. Liguori by Telethon n. GGP10138D and for T. Waseem by Federation of European Biochemical Societies (FEBS) Short Term Fellowship. 


\section{REFERENCES}

Arosio, D., Beltram, F., Ricci, F., and Marchetti, L. (2011). Novel pHand anion concentration-responsive GFP mutant, a chimeric protein comprising such a mutant and a method for the combined assaying of the $\mathrm{pH}$ and anion concentration. Eur. Pat. Appl. 08165 522.7-1212.

Arosio, D., Garau, G., Ricci, F., Marchetti, L., Bizzarri, R., Nifosì, R., et al. (2007). Spectroscopic and structural study of proton and halide ion cooperative binding to gfp. Biophys. J. 93, 232-244.

Arosio, D., Ricci, F., Marchetti, L., Gualdani, R., Albertazzi, L., and Beltram, F. (2010) Simultaneous intracellular chloride and $\mathrm{pH}$ measurements using a GFP-based sensor. Nat. Methods 7, 516-518.

Batti, L., Mukhtarov, M., Audero, E., Ivanov, A., Paolicelli, R., Zurborg, S., et al. (2013). Transgenic mouse lines for non-invasive ratiometric monitoring of intracellular chloride. Front. Mol. Neurosci.

Berglund, K., Kuner, T., Feng, G., and Augustine, G. J. (2011). Imaging synaptic inhibition with the genetically encoded chloride indicator Clomeleon. Cold Spring Harb. Protoc. 2011, 1492-1497.

Berglund, K., Schleich, W., Wang, H., Feng, G., Hall, W. C., Kuner, T., et al. (2008). Imaging synaptic inhibition throughout the brain via genetically targeted Clomeleon. Brain Cell Biol. 36, 101-118

Bertollini, C., Murana, E., Mosca, L., D’Erme, M., Scala, F., Francioso, A., et al. (2012) Transient increase in neuronal chloride concentration by neuroactive aminoacids released from glioma cells. Front. Mol. Neurosci. 5:100. doi: 10.3389/fnmol.2012.00100

Bregestovski, P., and Arosio, D. (2011). "Green fluorescent proteinbased chloride ion sensors for in vivo imaging," in Fluorescent Proteins, Springer Ser Fluoresc, ed G. Jung (Berlin, Heidelberg: Springer-Verlag), 90-124.

Bregestovski, P., Waseem, T., and Mukhtarov, M. (2009). Genetically encoded optical sensors for monitoring of intracellular chloride and chloride-selective channel activity. Front. Mol. Neurosci. 2:15. doi: 10.3389/neuro.02.015.2009

Buerli, T., Pellegrino, C., Baer, K., Lardi-Studler, B., Chudotvorova, I., Fritschy, J. M., et al. (2007). Efficient transfection of DNA or shRNA vectors into neurons using magnetofection. Nat. Protoc. 2, 3090-3101.

Dzhala, V., Valeeva, G., Glykys, J., Khazipov, R., and Staley, K. (2012). Traumatic alterations in GABA signaling disrupt hippocampal network activity in the developing brain. J. Neurosci. 32, 4017-4031.

Elsliger, M. A., Wachter, R. M., Hanson, G. T., Kallio, K., and Remington, S. J. (1999) Structural and spectral response of green fluorescent protein variants to changes in $\mathrm{pH}$. Biochemistry 38, 5296-5301.

Friedel, P., Bregestovski, P., and Medina, I. (2013). Improved method for efficient imaging of intracellular $\mathrm{Cl}^{-}$with $\mathrm{Cl}^{-}$Sensor using conventional fluorescence set up. Front. Mol. Neurosci. 6:7. doi: 10.3389/fnmol.2013.00007

Hanson, G. T., McAnaney, T. B., Park, E. S., Rendell, M. E., Yarbrough, D. K., Chu, S., et al. (2002). Green fluorescent protein variants as ratiometric dual emission $\mathrm{pH}$ sensors. 1 . Structural characterization and preliminary application. Biochemistry 41, 15477-15488.

Khirug, S., Yamada, J., Afzalov, R., Voipio, J., Khiroug, L., and Kaila, K. (2008). GABAergic depolarization of the axon initial segment in cortical principal neurons is caused by the Na-K-2Cl cotransporter NKCC1. J. Neurosci. 28 4635-4639.
Kuner, T., and Augustine, G. J. (2000) A genetically encoded ratiometric indicator for chloride: capturing chloride transients in cultured hippocampal neurons. Neuron 27, 447-459.

Mancuso, J. J., Kim, J., Lee, S., Tsuda, S., Chow, N. B., and Augustine, G. J. (2011). Optogenetic probing of functional brain circuitry. Exp. Physiol. 96, 26-33.

Marandi, N., Konnerth, A., and Garaschuk, O. (2002). Two-photon chloride imaging in neurons of brain slices. Pflugers Arch. 445, 357-365.

Markova, O., Mukhtarov, M., Real, E., Jacob, Y., and Bregestovski, P. (2008). Genetically encoded chloride indicator with improved sensitivity. J. Neurosci. Methods 170 67-76.

McCabe, J. B., and Berthiaume, L. G. (1999). Functional roles for fatty acylated amino-terminal domains in subcellular localization. Mol. Biol. Cell 10, 3771-3786.

Medina, I., Krapivinsky, G., Arnold S., Kovoor, P., Krapivinsky, L., and Clapham, D. E. (2000). A switch mechanism for $\mathrm{G}$ beta gamma activation of I(KACh). J. Biol. Chem. 275, 29709-29716.

Mukhtarov, M., Markova, O., Real, E., Jacob, Y., Buldakova, S., and Bregestovski, P. (2008). Monitoring of chloride and activity of glycine receptor channels using genetically encoded fluorescent sensors. Philos. Transact. A Math. Phys. Eng. Sci. 366, 3445-3462.

Pellegrino, C., Gubkina, O., Schaefer M., Becq, H., Ludwig, A., Mukhtarov, M., et al. (2011) Knocking down of the KCC2 in rat hippocampal neurons increases intracellular chloride concentration and compromises neuronal survival. J. Physiol. 589, 2475-2496.

Raimondo, J. V., Irkle, A., Wefelmeyer, W., Newey, S. E., and Akerman, C. J. (2012). Genetically encoded proton sensors reveal activitydependent $\mathrm{pH}$ changes in neurons. Front. Mol. Neurosci. 5:68. doi: 10.3389/fnmol.2012.00068

Tsien, R. Y., Pozzan, T., and Rink, T. J. (1982) Calcium homeostasis in intact lymphocytes: cytoplasmic free calcium monitored with a new intracellularly trapped fluorescent indicator. J. Cell Biol. 94, 325-334.

Tyzio, R., Minlebaev, M., Rheims, S., Ivanov, A., Jorquera, I., Holmes, G. L., et al. (2008). Postnatal changes in somatic gamma-aminobutyric acid signalling in the rat hippocampus. Eur. J. Neurosci. 27, 2515-2528.

Waseem, T., Mukhtarov, M., Buldakova, S., Medina, I., and Bregestovski, P. (2010). Genetically encoded $\mathrm{Cl}$-Sensor as a tool for monitoring of Cl-dependent processes in small neuronal compartments. J. Neurosci. Methods 193, 14-23.

Conflict of Interest Statement: The authors declare that the research was conducted in the absence of any commercial or financial relationships that could be construed as a potential conflict of interest.

Received: 01 February 2013; accepted: 02 April 2013; published online: 18 April 2013

Citation: Mukhtarov M, Liguori L Waseem T, Rocca F, Buldakova S, Arosio $D$ and Bregestovski P (2013) Calibration and functional analysis of three genet ically encoded $\mathrm{Cl}^{-} / \mathrm{pH}$ sensors. Front. Mol. Neurosci. 6:9. doi: 10.3389/fnmol. 2013.00009

Copyright (c) 2013 Mukhtarov, Liguori, Waseem, Rocca, Buldakova, Arosio and Bregestovski. This is an open-access article distributed under the terms of the Creative Commons Attribution License, which permits use, distribution and reproduction in other forums, provided the original authors and source are credited and subject to any copyright notices concerning any third-party graphics etc. 